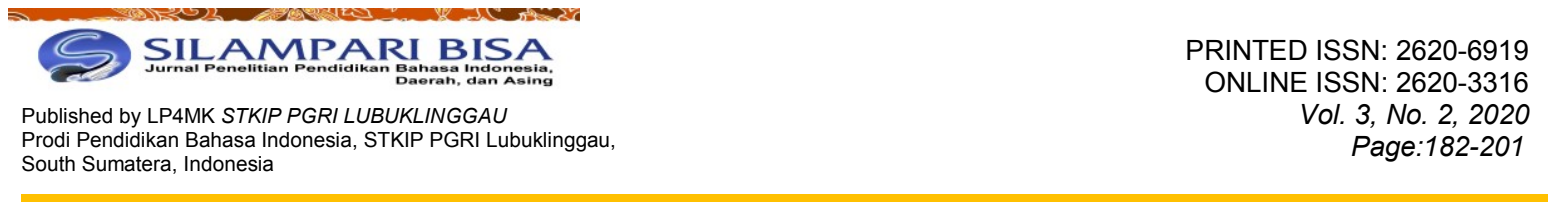

\title{
KEMAMPUAN DAN KESULITAN MAHASISWA PROGRAM STUDI PENDIDIKAN BAHASA INDONESIA UNIVERSITAS BENGKULU DALAM MENULIS PROPOSAL PENELITIAN SKRIPSI
}

\author{
Susetyo ${ }^{1}$, Noermanzah ${ }^{2}$ \\ ${ }^{1,2}$ Program Magister Pendidikan Bahasa Indonesia, Universitas Bengkulu \\ Jalan W.R. Supratman, Kandang Limun, Kota Bengkulu, Indonesia \\ Email: testyo55@gmail.com ${ }^{1}$,noermanzah@unib.ac.id ${ }^{2}$
}

Submitted: 1-September-2020

Accepted : 30-November-2020
Published: 8 December 2020

DOI: https://doi.org/10.31540/silamparibisa.v3i2

URL: https://doi.org/10.31540/silamparibisa.v3i2.1071

\begin{abstract}
Abstrak
Mahasiswa Program Studi Pendidikan Bahasa Indonesia Universitas Bengkulu mengalami kesulitan dalam penulisan proposal penelitian skripsi. Hal ini terbukti belum banyak mahasiswa yang lulus tepat waktu pada semester VIII. Tujuan penelitian ini mengetahui dan mendeskripsikan: (1) kemampuan mahasiswa dalam menulis proposal penelitian skripsi dan (2) kesulitan yang dihadapi mahasiswa dalam penulisan proposal penelitian skripsi. Metode yang digunakan dalam penelitian ini adalah metode deskriptif. Populasi penelitian ini adalah seluruh mahasiswa semester VII Program Studi Pendidikan Bahasa Indonesia tahun akademik 2017/2018. Sampel penelitian ini sebanyak 80 mahasiswa yang menulis proposal penelitian skripsi. Teknik pengambilan data berupa teknik dokumentasi dan wawancara. Analisis data untuk menanaisis data kuantitatif menggunakan rumus persentase, sedangkan untuk data kualitatif dianalisis dengan menggunakan model analisis Miles dan Huberman dengan langkah-langkah analisis reduksi data, display data, verifikasi, dan simpulan. Hasil penelitian menunjukkan bahwa kemampuan menulis proposal penelitian skripsi mahasiswa semester VII Program Studi Pendidikan Bahasa Indonesia tahun akademik 2017/2018 tergolong dalam kualifikasi cukup. Kemudian, mahasiswa mengalami kesulitan dalam menyusun proposal pada penulisan masalah dan rumusan masalah, penulisan landasan teori dan kajian pustaka, penentuan metode penelitian, teknik pengumpulan data dan penyusunan instrumen serta uji coba, rubrik penilaian, dan analisis data penelitian. Mahasiswa semester VII Program Studi Pendidikan Bahasa Indonesia Universitas Bengkulu hendaknya dibantu agar benar-benar memahami cara menyusun proposal penelitian skripsi agar mereka dapat menulis proposal penelitian dengan baik dan pada akhirnya mahasiswa akan dapat menyelesaikan skripsinya cepat dan tepat waktu.
\end{abstract}

Kata kunci: kemampuan, kesulitan, menulis proposal, penelitian skripsi

\section{THE ABILITIES AND DIFFICULTIES OF STUDENTS OF THE INDONESIAN LANGUAGE EDUCATION STUDY PROGRAM AT THE UNIVERSITY OF BENGKULU IN WRITING A THESIS RESEARCH PROPOSAL}

\begin{abstract}
Students of the Indonesian Language Education Study Program at the University of Bengkulu have difficulty writing a thesis research proposal. This is proven by not many students who passed on time in semester VIII. The purpose of this research is to identify and
\end{abstract}


describe: (1) the ability of students in writing thesis research proposals and (2) the difficulties faced by students in writing thesis research proposals. The method used in this research is descriptive method. The population of this study was all students of semester VII of the Indonesian Language Education Study Program in the 2017/2018 academic year. The sample of this research is 80 students who write thesis research proposals. The data collection techniques were documentation and interview techniques. Data analysis to analyze quantitative data used the percentage formula, while for qualitative data it was analyzed using the Miles and Huberman analysis model with the steps of data reduction analysis, data display, verification, and conclusions. The results showed that the ability to write thesis research proposals for seventh semester students of the Indonesian Language Education Study Program for the academic year 2017/2018 was classified as sufficient qualification. Then, students experience difficulties in compiling proposals in writing problems and problem formulations, writing theoretical foundations and literature reviews, determining research methods, data collection techniques and arranging instruments as well as testing, assessment rubrics, and research data analysis. The seventh semester students of the Indonesian Language Education Study Program at the University of Bengkulu should be assisted so that they really understand how to compile a thesis research proposal so that they can write a research proposal well and in the end students will be able to complete their thesis quickly and on time.

Keywords: ability, difficulty, writing proposals, thesis research

\section{A. Pendahuluan}

Kemampuan penulisan proposal penelitian sudah pernah ditingkatkan oleh Ardimen (2017:64) kepada calon konselor melalui metode Problem Based Learning dengan hasil penelitian yang menunjukkan bahwa terjadinya peningkatan kemmapuan calon konselor dalam memilih dan merumuskan judul secara aktual, menulis latar belakang, membatasi dan merumuskan masalah, merumuskan tujuan yang sesuai dengan rumusan masalah penelitian, merumuskan kegunaan penelitian, memilih dan menggunakan teori yang faktual dan aktual, memilih metode yang sesuai dengan masalah dan tujuan penelitian, serta kemampuan mengikuti format proposal penelitian. Akan tetapi, terdapat beberapa hal yang menjadi pusat perhatian untuk ditingkatkan dalam penulisan proposal penelitian yaitu kemampuan mereduksi konsep/teori yang digunakan, kemampuan menggunakan notasi ilmiah dan tata bahasa, kemampuan memilih teknik sampling dan/ atau informan penelitian yang sesuai dengan penetapan masalah penelitian, kemampuan memilih teknik pengumpulan data, instrumen penelitian, teknik pengolahan dan analisis data yang sesuai dengan masalah dan tujuan penelitian, dan kelengkapan referensi pendukung konsep (Ardimen, 2017:93). 
Kemudian, Aisiah \& Firza (2019:149) lebih pada melihat kendala yang dihadapi oleh mahasiswa Jurusan Sejarah Universitas Negeri Padang dalam menulis proposal skripsi. Kendala yang dihadapi mulai dari menulis proposal jenis kualitatif, kuantitatif, PTK, dan R\&D. Kendala yang dihadapi mahasiswa berkaitan dalam cara merumuskan masalah penelitian sesuai fenomena di lapangan, menuangkan teknik pengumpulan data dan teknik analisis data, serta khusus untuk penelitian R\&D kendalanya seputar spesifikasi produk yang sesuai dengan harapan dan kebutuhan pengguna.

Kristanto dkk. (2014) dalam penelitiannya lebih menjelaskan bahwa terdapat hubungan antara kepercayaan diri dengan kecemasan dalam menyusun proposal skripsi sehingga menimbulkan kendala-kendala yang membuat mahasiswa kesulitan dalam menyusun proposal skripsi. Hal ini berbeda dengan penelitian yang dilakukan dalam pembahasan ini yang bertujuan melihat kemampuan dan tingkat kesulitan menulis proposal penulisan skripsi khususnya pada mahasiswa Program Studi Pendidikan Bahasa Indonesia, FKIP Universitas Bengkulu. Tujuannya agar bisa melihat secara langsung permasalahan yang dihadapi mahasiswa sehingga bisa menjadi perbaikan di masa mendatang bagi pengelola, pembimbing, dan mahasiswa dalam menyusun proposal penelitian skripsi dengan benar dan selesai tepat waktu.

Rasa penasaran untuk meneliti kemampuan mahasiswa dalam menulis proposal penelitian skripsi muncul dan termotivasi ketika mahasiswa yang dapat menyelesaikan skripsi pada bulan April tahun 2020 hanya 1 orang mahasiswa, yang kebetulan mahasiswa merupakan mahasiswa bimbingan skripsi peneliti. Ini berarti masih ada 63 mahasiswa lagi yang masih dalam proses bimbingan skripsi, baik dari mahasiswa Program Studi Pendidikan Bahasa Indonesia semester VIII Kelas A maupun semester VIII Kelas B. Hal ini dapat ditunjukkan pada tabel berikut. 
Tabel 1. Perkembangan Mahasiswa Program Studi Pendidikan Bahasa Indonesia dalam Penyelesaian Skripsi yang Masuk Tahun Tahun Akademik 2016/3017

\begin{tabular}{ccccc}
\hline Jumlah Mahasiswa & Jumlah & Jumlah Mahasiswa & Jumlah Mahasiswa \\
yang Masuk Tahun & Mahasiswa Proses & yang Telah Seminar & Proses akan Ujian & Jumlah \\
Akademik & Bimbingan & Proposal Penelitian & Hasil Penelitian & Lulus \\
$2016 / 2017$ & Proposal & Skripsi & Skripsi & \\
\hline
\end{tabular}

64

26

36

1

1

Dari tabel di atas diperoleh informasi dari Program Studi Pendidikan Bahasa Indonesia Jurusan Pendidikan Bahasa dan Seni Fakultas Keguruan dan IImu Pendidikan bahwa dari 64 mahasiswa angkatan 2016/2017 yang telah lulus bulan April 2020 ada 1 orang, sedangkan yang belum lulus, ada 63 mahasiswa. Dari 63 mahasiswa yang belum lulus, yang dalam proses bimbingan ada 26 mahasiswa dan yang telah seminar proposal sebanyak 36 dan ada 1 mahasiswa yang sedang menunggu ujian seminar hasil.

Dari data di atas jelas menunjukkan bahwa kemampuan mahasiswa dalam menulis proposal tidak tinggi dan mahasiswa mengalami kendala dan kesulitan dalam menulis proposal skripsi. Hal ini sudah dapat diprediksi banyak mahasiswa pada bulan Agustus akhir semester VIII belum bisa menyelesaikan skripsinya. Padahal Program Studi yang sangat baik seharusnya telah dapat meluluskan mahasiswanya pada semester VIII paling tidak sebanyak $50 \%$ dari keseluruhan angkatan 2016/2017, berarti paling tidak dapat meluluskan sebanyak 32 mahasiswa.

Kesulitan menyusun proposal penelitian skripsi bagi mahasiswa merupakan hal yang klasik, padahal mahasiswa sudah mendapat Matakuliah Penelitian Pendidikan Bahasa dan Sastra, Penelitian Bahasa dan Sastra, Seminar (Pengajaran, Kebahasaan, dan Sastra), namun masih tetap saja mahasiswa mengalami kesulitan dan kendala yang mereka alami ketika menyusun proposal penelitian skripsi. Hal ini juga seperti hasil penelitian yang dilakukan oleh Aisiah \& Firza (2019) bahwa mahasiswa pada umumnya mengalami kendala dalam penulisan proposal penelitian skripsi terutama dalam menuangkan latar belakang, kerangka berpikir, instrumen penelitian, analisis data, dan uji kebasahan data. Begitu juga penelitian yang sudah dilakukan oleh Zuriati (2020:7) menunjukkan 
bahwa $60 \%$ mahasiswa masih kesulitan dalam menulis proposal skripsi mulai dari menulis bagian pendahuluan, landasan teori, dan daftar pustaka.

Pada ketiga materi matakuliah, yakni (1) Penelitian Pendidikan Bahasa dan Sastra, (2) Penelitian Bahasa dan Sastra, dan (3) Seminar (Pengajaran, Kebahasaan, dan Sastra) seharusnya mahasiswa telah memiliki pengetahuan dan pemahaman serta keterampilan membuat proposal penelitian skripsi karena pada ketiga materi kuliah tersebut mahasiswa diberi tugas untuk membuat proposal dan juga proposal yang mereka buat didiskusikan pada matakuliah Seminar (Pengajaran, Kebahasaan, dan Sastra) dan didampingi oleh tim dosen yang terdiri atas dosen pengajaran, dosen kebahasaan, dan dosen sastra.

Buku pedoman menulis skripsi juga telah dibagikan oleh program studi kepada mahasiswa, tampaknya pada umumnya mahasiswa jarang membaca buku panduan. Mereka menyusun proposal penelitian skripsinya hanya meniru pada skripsi dari mahasiswa tahun sebelumnya atau dari mahasiswa yang lebih dahulu lulus. Mereka menyusun proposal penelitian skripsi tidak mempelajari secara mendalam dari teori membuat proposal yang ada di dalam panduan penulisan skripsi. Selain hal itu berdasarkan pengalaman peneliti, mahasiswa mengalami kesulitan ketika menyusun latar belakang masalah, mengurutkan kerangka teori dan kajian pustaka, dan dalam metodologi mereka mengalami kesulitan memilih metode, menyusun instrumen penelitian, dan analisis data, baik analisis data kuantitatif maupun data kualitatif.

Menulis proposal merupakan keharusan bagi mahasiswa calon sarjana yang akan terjun ke lapangan atau mengambil data (Susetyo \& Noermanzah, 2020). Setelah proposal penelitian diajukan kepada pembimbing, baik Pembimbing Utama (Pembimbing I) maupun Pembimbing Pendamping (Pembimbing II), dan diuji dalam ujian seminar serta dinyatakan lulus oleh dosen pembimbing dan penguji, mahasiswa baru diperbolehkan untuk mengambil data. Proposal penelitian ini merupakan syarat mutlak dalam penyelesaian skripsi mahasiswa, tanpa proposal penelitian, tentu laporan penelitian skripsinya tidak akan terwujud. 
Dari uraian di atas permasahan ini sangat mendesak untuk diteliti agar segera mendapat gambaran yang jelas tentang kemampuan mahasiswa dalam menyusun proposal penelitian skripsi dan kesulitan apa saja yang dialami mahasiswa semester VII Pendidikan Bahasa Indonesia Jurusan Pendidikan Bahasa dan Seni FKIP Universitas Bengkulu dalam menulis proposal penelitian skripsi.

\section{B. Metode Penelitian}

Metode yang digunakan dalam penelitian ini adalah metode deskriptif. Penelitian deskriptif ini dilakukan untuk menjawab dan mendeskripsikan persoalan-persoalan yang terjadi atau berlaku pada saat sekarang ini (Susetyo, 2019:15). Penelitian ini dilaksanakan di Universitas Bengkulu, tepatnya pada Program Studi Pendidikan Bahasa Indonesia, Jurusan Pendidikan Bahasa dan Seni FKIP. Waktu penelitian dilaksanakan dari bulan Juli sampai dengan November 2020.

Populasi penelitian adalah semua mahasiswa yang sedang mengajukan proposal penelitian sebanyak 106 mahasiswa, terdiri atas kelas A sebanak 34, kelas B sebanyak 36, dan kelas C sebanyak 38 mahasiswa. Sampel penelitian sampel penelitian sebanyak 80 mahasiswa atau sebanyak $75 \%$. Teknik pengumpulan data yang digunakan dalam penelitian adalah tes membuat proposal, wawancara, dan dokumentasi. Hasil tes menyusun proposal skripsi adalah yang dibuat oleh mahasiswa semester VIII A, B, dan C. Wawancara tulis digunakan untuk mengambil data tentang kesulitan yang dialami mahasiswa semester VII Program Studi Pendidikan Bahasa Indonesia dalam menyusun proposal penelitian skripsi.

Instrumen yang digunakan untuk mengukur kemampuan menulis proposal adalah rubrik penilaian terhadap kemampuan membuat proposal. Pengumpulan data kesulitan yang dialami mahasiswa dalam menyusun proposal penelitian skripsi menggunakan pertanyaan terbuka melalui WhatsApp (WA). Data penelitian kuantitatif berupa kemampuan menulis proposal penelitian skripsi dianalisis dengan menggunakan rumus persentase, sedangkan untuk menganalisis data 
kualitatif digunakan analisis data model Miles dan Huberman dengan langkahlangkah reduksi data, display data, dan verifikasi serta simpulan. Uji keabsahan data menggunakan triangulasi sumber data yang diperoleh dari data tes membuat proposal, hasil wawancara, dan dokumentasi pelaksanaan penelitian.

\section{Hasil Penelitian dan Pembahasan}

\section{Hasil Penelitian}

Hasil penelitian kemampuan mahasiswa semester VII Pendidikan Bahasa Indonesia dalam menulis proposal penelitian skripsi yang meliputi aspek menulis judul, masalah dan rumusan masalah, manfaat penelitian, landasan teori dan kajian pustaka, dan metodologi penelitian dan terdapat beberapa kesulitan yang dialami mahasiswa dalam menulis proposal penelitian yang akan dijelaskan pada bagian berikut.

\section{a. Kemampuan Mahasiswa dalam Menulis Proposal Penelitian Skripsi}

Hasil penelitian kemampuan mahasiswa semester VII Pendidikan Bahasa Indonesia dalam menulis proposal penelitian skripsi yang mencakup aspek judul, masalah dan rumusan masalah, landasan teori dan kajian pustaka, metodologi penelitian, dan aspek sistematika menulis proposal penelitian skripsi dapat dilihat pada tabel 2 di bawah ini.

Tabel 2. Kemampuan Mahasiswa dalam Menulis Proposal Penelitian Skripsi

\begin{tabular}{clcc}
\hline No. & \multicolumn{1}{c}{ Aspek } & Nilai & Kualifikasi \\
\hline 1 & Judul & 75,18 & baik \\
\hline 2 & $\begin{array}{l}\text { Masalah dan Rumusan } \\
\text { Masalah }\end{array}$ & 63,06 & cukup \\
\hline 3 & Manfaat Penelitian & $\mathbf{7 5 , 9 9}$ & baik \\
\hline 4 & $\begin{array}{l}\text { Landasan Teori dan } \\
\text { Tinjauan Pustaka }\end{array}$ & 64,50 & cukup \\
\hline 5 & Metodologi Penelitian & 63,81 & cukup \\
\hline 6 & $\begin{array}{l}\text { Sistematika Penulisan } \\
\text { Proposal }\end{array}$ & 65,19 & cukup \\
\hline & Total & 407,73 & cukup \\
\hline
\end{tabular}

Silampari Bisa: Jurnal Penelitian Pendidikan Bahasa Indonesia, Daerah, dan Asing Vol. 3, No. 2, 2020 


$\begin{array}{lll}\text { Catatan: } & 85-100 & \text { : Sangat Baik } \\ & 75-84 & \text { : Baik } \\ 60-74 & \text { : Cukup } \\ & 50-59 & \text { : Kurang } \\ & 0-49 & \text { : Sangat Kurang }\end{array}$

Tabel 2 di atas menunjukkan bahwa kemampuan mahasiswa semester VII Pendidikan Bahasa Indonesia dalam menulis proposal penelitian skripsi rata-rata 67,95 berada pada kualifikasi cukup. Rata-rata nilai untuk penulisan manfaat sebesar 75,99 dengan kualifikasi baik, menulis judul sebesar 75,18, termasuk pada kualifikasi baik, menulis landasan teori dan tinjauan pustaka sebesar 64,50 pada kualifikasi cukup, menulis sistematika penulisan sebesar 65,19 termasuk kategori cukup, menulis metodologi penelitian sebesar 63,81 dalam kualifikasi cukup, dan menulis masalah dan rumusan masalah sebesar 63,06 termasuk kategori cukup.

Tabel 3. Kemampuan Menulis Proposal Penelitian Skripsi Mahasiswa pada Aspek Judul

\begin{tabular}{cccc}
\hline No. & Rentang & Frekuensi & Kualifikasi \\
\hline 1. & $85-100$ & 0 & Sangat Baik \\
\hline 2. & $75-84$ & 2 & Baik \\
\hline 3. & $60-74$ & 66 & Cukup \\
\hline 4. & $50-59$ & 12 & Kurang \\
\hline 5. & $0-49$ & 0 & Sangat Kurang \\
\hline
\end{tabular}

Tabel 3 di atas menunjukkan bahwa kemampuan mahasiswa dalam menulis proposal penelitian skripsi dilihat dari aspek judul penelitian sebanyak 66

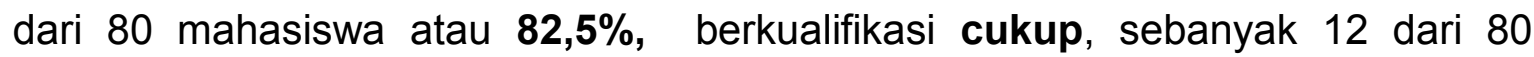
mahasiswa 15\% berkualifikasi kurang, dan 2 dari 80 mahasiswa atau 2,5\% berkualifikasi baik, sedangkan kemampuan mahasiswa yang berkualifikasi sangat baik dan sangat kurang (0\%). 
Tabel 4. Kemampuan Menulis Proposal Penelitian Skripsi Mahasiswa pada Aspek Masalah dan Rumusan Masalah Proposal Skripsi

\begin{tabular}{clcl}
\hline No. & \multicolumn{1}{c}{ Rentang } & Frekuensi & \multicolumn{2}{c}{ Kualifikasi } \\
\hline 1 & $85-100$ & 0 & Sangat Baik \\
\hline 2 & $75-84$ & 0 & Baik \\
\hline 3 & $60-74$ & 67 & Cukup \\
\hline 4 & $50-59$ & 13 & Kurang \\
\hline 5 & $0-49$ & 0 & Sangat Kurang \\
\hline & Jumlah & 80 & \\
\hline
\end{tabular}

Tabel 4 di atas menunjukkan bahwa kemampuan mahasiswa dalam menulis proposal penelitian skripsi dilihat dari aspek masalah dan rumusan masalah penelitian sebanyak 67 dari 80 mahasiswa atau $83,75 \%$, berkualifikasi cukup, sebanyak 13 dari 80 mahasiswa 16,25\% berkualifikasi kurang, sedangkan kemampuan mahasiswa yang berkualifikasi sangat baik, baik, dan sangat kurang $(0 \%)$.

Tabel 5. Kemampuan Menulis Proposal Penelitian Skripsi Mahasiswa pada Aspek Manfaat

\begin{tabular}{clcl}
\hline No. & Rentang & Frekuensi & Kualifikasi \\
\hline 1 & $85-100$ & 0 & Sangat Baik \\
\hline 2 & $75-84$ & 40 & Baik \\
\hline 3 & $60-74$ & 40 & Cukup \\
\hline 4 & $50-59$ & 0 & Kurang \\
\hline 5 & $0-49$ & 0 & Sangat Kurang \\
\hline & Jumlah & 80 & \\
\hline
\end{tabular}

Tabel 5 di atas menunjukkan bahwa kemampuan mahasiswa dalam menulis proposal penelitian skripsi dilihat dari aspek manfaat sebanyak 40 dari 80 mahasiswa atau $\mathbf{5 0 \%}$, berkualifikasi baik, sebanyak 40 dari 80 mahasiswa $\mathbf{5 0} \%$ berkualifikasi cukup, sedangkan kemampuan mahasiswa yang berkualifikasi sangat baik, kurang dan sangat kurang $(0 \%)$. 
Tabel 6. Kemampuan Menulis Proposal Penelitian Skripsi Mahasiswa pada Aspek Landasan Teori dan Tinjauan Pustaka

\begin{tabular}{cccl}
\hline No. & Rentang & Frekuensi & \multicolumn{1}{c}{ Kualifikasi } \\
\hline 1 & $85-100$ & 0 & Sangat Baik \\
\hline 2 & $75-84$ & 7 & Baik \\
\hline 3 & $60-74$ & 67 & Cukup \\
\hline 4 & $50-59$ & 6 & Kurang \\
\hline 5 & $0-49$ & 0 & Sangat Kurang \\
\hline & Jumlah & 80 & \\
\hline
\end{tabular}

Pada tabel 6 di atas ditunjukkan bahwa kemampuan mahasiswa dalam menulis proposal penelitian skripsi dilihat dari aspek landasan teori dan tinjauan pustaka sebanyak 7 dari 80 mahasiswa atau $\mathbf{8 , 7 5 \%}$ berkualifikasi baik, sebanyak 67 dari 80 mahasiswa atau 83,75\% berkualifikasi cukup, dan sebanyak 6 dari 80 mahasiswa $7,5 \%$ berkualifikasi kurang, sedangkan kemampuan mahasiswa yang berkualifikasi sangat baik dan sangat kurang tidak ada (0\%).

Tabel 7. Kemampuan Menulis Proposal Penelitian Skripsi Mahasiswa pada Aspek Metodologi Penelitian

\begin{tabular}{cccc}
\hline No. & Rentang & Frekuensi & Kualifikasi \\
\hline 1 & $85-100$ & 0 & Sangat Baik \\
\hline 2 & $75-84$ & 0 & Baik \\
\hline 3 & $60-74$ & 71 & Cukup \\
\hline 4 & $50-59$ & 9 & Kurang \\
\hline 5 & $0-49$ & 0 & Sangat Kurang \\
\hline & Jumlah & 80 & \\
\hline
\end{tabular}

Tabel 7 di atas menunjukkan bahwa kemampuan mahasiswa dalam menulis proposal penelitian skripsi dilihat dari aspek metodologi sebanyak 71 dari 80 mahasiswa atau $\mathbf{8 8 , 7 5 \%}$ berkualifikasi cukup, dan sebanyak 9 dari 80 mahasiswa atau $11,25 \%$ berkualifikasi kurang, sedangkan kemampuan mahasiswa yang berkualifikasi sangat baik, baik, dan sangat kurang tidak ada (0\%). 
Tabel 8. Kemampuan Menulis Proposal Skripsi Mahasiswa pada Aspek Sistematika Penulisan Proposal Penelitian Skripsi

\begin{tabular}{cccl}
\hline No. & Rentang & Frekuensi & \multicolumn{1}{c}{ Kualifikasi } \\
\hline 1 & $85-100$ & 0 & Sangat Baik \\
\hline 2 & $75-84$ & 12 & Baik \\
\hline 3 & $60-74$ & 68 & Cukup \\
\hline 4 & $50-59$ & 0 & Kurang \\
\hline 5 & $0-49$ & 0 & Sangat Kurang \\
\hline & Jumlah & 80 & \\
\hline
\end{tabular}

Tabel 8 di atas menunjukkan bahwa kemampuan mahasiswa dalam menulis proposal penelitian skripsi dilihat dari aspek sistematika penulisan sebanyak 68 dari 80 mahasiswa atau $\mathbf{8 5 \%}$ berkualifikasi baik, dan sebanyak 12 dari 80 mahasiswa atau $15 \%$ berkualifikasi cukup, sedangkan kemampuan mahasiswa yang berkualifikasi sangat baik, baik dan sangat kurang tidak ada $(0 \%)$.

\section{b. Kesulitan Menulis Proposal Penelitian Skripsi}

Hasil penelitian tentang Problematik Menulis Proposal Skripsi Mahasiswa Semester 7 Prodi Pendidikan Bahasa Indonesia didapat dari hasil wawancara melalui WhatsApp (WA) terhadap mahasiswa yang dikelompokkan menjadi 3 bagian, yaitu (1) Bagian Pendahuluan, (2) Bagian Landasan Teori, dan (3) Bagian Metodologi Penelitian.

1) Kesulitan Menulis Proposal pada Bagian Pendahuluan

Hasil penelitian tentang kesulitan menulis proposal skripsi mahasiswa Semester 7 Program Studi Pendidikan Bahasa Indonesia didapat dari hasil wawancara melalui WhatsApp (WA) terhadap mahasiswa yang dikelompokkan menjadi 3 bagian, yaitu (1) Bagian Pendahuluan, (2) Bagian Landasan Teori, dan (3) Bagian Metodologi Penelitian.

2) Kesulitan Menulis Proposal pada Bagian Pendahuluan

Sebagian besar mahasiswa menyatakan bahwa mereka mengalami kesulitan membuat proposal penelitian skripsi pada Bab I Pendahuluan, 
khususnya pada penulisan atau penuangan tentang masalah dan rumusan masalah, dan mengembangkannya serta mengidentifikasi masalah, seperti yang pernyataan sebagai berikut.

... kesulitan membuat proposal penelitian yg saya alami pada BAB 1, yaitu: kesulitan menguraikan masalah dan membuat rumusan masalah masih bingung

...saya merasa sulit ketika ingin membuat latar belakang dan mengembangkan latar belakang.

... kesulitan yang sering saya alami dalam membuat proposal adalah pada BAB 1 saya masih merasa sulit ketika ingin membuat latar belakang dan mengembangkan latar belakang itu, serta ketika mengidentifikasi permasalahannya saya belum terlalu mahir.

Selain mengalami kesulitan dalam menuangkan gagasan atau masalah pada latar belakang dan rumusan masalah serta mengidentikasi masalah, mahasiswa juga mengalami kesulitan dalam membedakan antara definisi istilah dan definisi operasional, seperti yang dinyatakan pada pernyataan mahasiswa di bawah ini.

.... Kesulitan dalam membuat proposal penelitian yg saya alami pada bab 1 yaitu :pada proses pembuatan latar belakang dan saat mengidentifikasi masalah yg terjadi.Sebab penggambaran masalah haruslah sesuatu yang memang relevan dengan masalah yang di temui dalam keseharian,dan kita minta seakan bercerita tentang fokus masalah yang ingin diteliti tersebut.Dan sering bingung membedakan antara definisi istilah dan definisi operasional.

3) Kesulitan Menulis Proposal pada Bagian Landasan Teori dan Kajian Pustaka Mahasiswa semester VII Program Pendidikan Bahasa Indonesia mengalami kesulitan dalam menulis BAB II, yaitu menulis Landasan atau kerangka Teori dan Kajian Pustaka yang dikutip dari buku, jurnal, dan yang lain, sebagaimana pernyataan mahasiswa berikut ini.

\footnotetext{
... kesulitan yang saya hadapi dalam menulis Landasan Teori dan Kajian Pustaka pada BAB II, yaitu mengenai teori apa saja yang harus saya masukkan berkaitan dengan variabel penelitian dan teorinya dari berapa jumlah ahli.

...untuk pada bab 2, kendala yang saya hadapi yaitu pada penulisan kajian pustaka, dalam menulis kajian pustaka harus bersumber dari banyak referensi baik buku, jurnal, dan lain-lain, kendalanya adalah buku yang sulit ditemukan atau bahkan buku yang relevan dengan penelitian yang saya lakukan sedikit sekali.

...pada bab 2, kendala yang saya hadapi yaitu pada penulisan kajian pustaka, dalam menulis kajian pustaka harus bersumber dari berbagai referensi baik buku, jurnal, dan lain-lain, kendalanya adalah buku yang sulit ditemukan atau bahkan buku yang relevan dengan penelitian yang saya lakukan susah untuk menemukannya.
}

Silampari Bisa: Jurnal Penelitian Pendidikan Bahasa Indonesia, Daerah, dan Asing Vol. 3, No. 2, 2020 
Kemampuan dan Kesulitan Mahasiswa Program Studi Pendidikan Bahasa Indonesia Universitas Bengkulu dalam Menulis Proposal Penelitian Skripsi

Selain mengalami kesulitan dalam menulis landasan teori dan kajian pustaka, mahasiswa juga mengalami kesulitan dalam kerangka berpikir dan pengajuan hipotesis, seperti pernyataan mahasiswa seperti di bawah ini.

... kesulitan pada bab II ini ialah dalam membuat hipotesis yang ingin saya ajukan pak,dan juga saya masih merasa kesulitan membuat kerangka berpikir untuk masalah yang akan diteliti.

Para mahasiswa semester VII Program Studi Pendidikan Bahasa Indonesia mengalami kesulitan untuk menemukan teori yang tepat dari referensi yang jelas dan sesuai dalam penulisan landasan teori dan kajian pustaka, seperti yang dinyatakan oleh mahasiswa sebagaimana dalam pernyataan di bawah ini.

... kesulitan saya pada menentukan teori yang tepat karena harus mengambil referensi yang jelas.

... masih sulit untuk menemukan referensi yang sesuai dengan kajian proposal teori dalam pembuatan proposal.

4) Kesulitan Menulis Proposal Penelitian Skripsi pada Bagian Metodologi

Penelitian

Berkaitan dengan penulisan pada metodologi penelitian proposal penelitian skripsi sebagian besar besar mahasiswa mengemukakan jawabannya sebagai berikut.

... Bab 3: dalam menentukan metode penelitian apa yg harus dipakai, itu agak sulit bapak, akan tetapi yg paling sulit di bab ini pada saat pembuatan instrumen dan uji coba instrumen.. Serta pada saat menentukan salah satu dari teknik pengambilan data dan teknik analisis data. 2 teknik tsb khususnya Berlian masih bingung pak dan belum mengerti dan paham.

...kendala yang saya alami dalam menulis proposal Bab 3 adalah metode penelitian masih kurang paham dengan eksperimen semu dan quasi eksperimen pada kuantitatif. Selanjutnya pada teknik pengambilan data dan teknik analisis data. Karena dengan adanya kuliah seminar kemarin masih banyak yang salah dalam menentukan ini.

... pada bab 3 masih tidak memahami bagaimana pengambilan sampel dan jenis sampel apa yang cocok dalam proposal dan juga pada statistik penelitian yang harus menggunakan rumus apa yang sesuai dengan data, mungkin untuk statistik dapat di bantu bimbingan akan rumus-rumus yang harus digunakan pak. Mungkin itu pak, terima kasih.

Silampari Bisa: Jurnal Penelitian Pendidikan Bahasa Indonesia, Daerah, dan Asing Vol. 3, No. 2, 2020 
Dari pernyataan di atas dapat ditunjukkan bahwa mahasiswa mengalami kesulitan pada penulisan BAB III Metodologi Penelitian, yaitu pada penentuan metode penelitian, pengambilan sampel dan jenis sampel, instrumen dan teknik pengumpulan data, dan penggunaan rumus statistik dalam analisis data.

\section{Pembahasan}

\section{a. Kemampuan Mahasiswa dalam Menulis Proposal Penelitian Skripsi}

Hasil penelitian kemampuan mahasiswa semester 7 Program Studi Pendidikan Bahasa Indonesia dalam menulis proposal penelitian skripsi yang diuraikan di bawah ini mencakup aspek judul, masalah dan rumusan masalah, landasan teori dan kajian pustaka, metodologi penelitian, dan aspek sistematika menulis proposal penelitian skripsi diuraikan sebagai berikut.

Dari hasil penelitian terhadap 80 proposal penelitian skripsi menunjukkan bahwa kemampuan mahasiswa semester VII Program Studi Pendidikan Bahasa Indonesia dalam menulis proposal penelitian skripsi tergolong dalam kualifikasi cukup. Hal ini dapat dikatakan bahwa secara keseluruhan kemampuan mahasiswa dalam menulis proposal penelitian skripsi masih belum memuaskan, padahal mahasiswa telah lulus Matakuliah Penelitian Pendidikan Bahasa dan Sastra, Matakuliah Penelitian Bahasa dan Sastra, dan Seminar Pendidikan Bahasa dan Sastra Indonesia. Hal ini sama dengan hasil penelitian yang dilakukan oleh Doni \& Edi, (2019) bahwa kemampuan mahasiswa di Fakultas Ekonomi Universitas Tridinanti Palembang dalam menulis proposal penelitian masih tergolong cukup terutama belum mampu menuangkan latar belakang yang menjelaskan posisi penelitian dan kebaruan penelitian yang bersumber dari jurnal nasional dan internasional.

Ditinjau dari aspek-aspek dalam penulisan proposal dapat diuraikan sebagai berikut. Dari aspek penulisan judul proposal penelitian skripsi kemampuan sebagian besar mahasiswa berkualifikasi baik atau $82,5 \%$ telah mampu menulis atau merumuskan judul penelitian dengan baik. Dalam menulis atau merumuskan judul mahasiswa semester VII Program Studi Pendidikan Bahasa Indonesia FKIP Universitas Bengkulu telah memperhatikan jenis 
pendekatan penelitian, objek dan subjek penelitian seta tempat dantahun penerbitan dalam penelitian kuantitatif. Hal ini sesuai dengan apa yang dikemukakan Susetyo (2019:73) bahwa judul yang lengkap mengandung (1) sifat dan jenis penelitian korelasi, perbandingan atau eksperimen, (2) objek penelitian, (3) subjek penelitian, (4) tempat penelitian, dan waktu penelitian. Selain itu, mahasiswa juga telah menggunakan kata-kata baku dan tidak menggunakan kata singkatan. Judul yang ditulis sebagian besar sudah disesuaikan dengan topik masalah. Judul penelitian kuantitatif yang dirumuskan mahasiswa sudah sesuai dengan jenis dan metode penelitian, seperti korelasi, perbandingan, eksperimen. Dalam merumuskan judul penelitian kualitatif mahasiswa telah menggunakan kata yang tepat seperti kesulitan, analisis, kajian, problematka, sedangkan penelitian tindakan kelas telah menggunakan kata peningkatan dan menggunakan model atau media tertentu.

Dilihat dari aspek menulis atau menguraikan masalah dan rumusan masalah dalam penulisan proposal penelitian skripsi, kemampuan mahasiswa semester VII Program Studi Pendidikan Bahasa Indonesia berkualifikasi cukup. Hal ini berarti bahwa mahasiswa belum mampu menguraikan masalah dan merumuskan masalah dalam proposal penelitian skripsi. Hal ini mendukung hasil penelitian Gani (2015) yang menyatakan bahwa secara umum mahasiswa mengalami kesulitan dalam penuangan ide dan masalah ke dalam tulisan ilmiah.

Hal tersebut senada dengan pendapat Gani (2019:330) yang mengemukakan bahwa banyak mahasiswa belum mampu mengemukakan latar belakang mengenai topik atau isu yang akan diangkat dalam penelitian sesuai dengan perkembangan situasi dan kondisi dewasa ini. Pada bagian ini, umumnya mahasiswa belum mampu mengemukakan posisi topik yang akan diteliti dan belum mampu menyatakan adanya gap (kesenjangan) yang perlu diisi dengan melakukan pendalaman terhadap topik yang akan diteliti.

Rumusan masalah hendaknya merupakan rumusan persoalan yang perlu dipecahkan atau pertanyaan yang perlu dijawab dengan penelitian. Rumusan itu tidak harus dalam bentuk kalimat tanya, tetapi hendaklah mengandung kata-kata 
yang menyatakan persoalan atau pertanyaan, yakni, siapa, berapa, seberapa, sejauh mana, bagaimana (bisa tentang cara atau wujud/keadaan), di mana, ke mana, dari mana, mengapa, dan sebagainya ( Tim Penyusun Fakultas IImu Pendidikan, Universitas Negeri Semarang, 2017:11).

Dilihat dari segi penulisan manfaat proposal penelitian skripsi sebanyak 50\% kemampuan mahasiswa semester VII Program Studi Pendidikan Bahasa Indonesia berkualifikasi cukup tergolong baik dan 50\% selebihnya berkualifikasi cukup. Hal ini berarti mahasiswa telah mampu menulis manfaat penelitian, namun masih perlu lebih operasional lagi dalam menuliskan manfaat penelitian. Seperti yang disampaikan Gani (2019:33) \& Sanjaya (2014) bahwa dalam menuliskan kegunaan penelitian dalam proposal penelitian skripsi hendaknya dipaparkan pentingnya hasil penelitian tersebut, baik bermanfaat bagi pengembangan ilmu (kegunaan teoretis) maupun bagi kepentingan praktis (kegunaan praktis) secara jelas dan operasional.

Kemampuan mahasiswa dalam menulis proposal penelitian skripsi dilihat dari aspek landasan teori dan tinjauan pustaka berkualifikasi cukup. Hal ini menandakan bahwa sebagian besar mahasiswa Program Studi Pendidikan Bahasa Indonesia FKIP Universitas Bengkulu belum mampu menulis landasan teori dan kajian pustaka secara baik. Dalam penulisan landasan teori hendaknya dinyatakan teori yang tdigunakan untuk landasan kerja penelitian. Dalam penulisan landasan teori itu bisa disusun sendiri secara eklektik, berupa teori yang digunakan oleh seorang ahli, atau hasil sintesis atas sejumlah teori yang relevan.

Dalam menulis tinjauan (kajian) pustaka mahasiswa masih perlu diuraikan kajian pustaka yang mendukung pendekatan pemecahan masalah. Tingkat kedalaman dan keluasan aspek-aspek yang diteliti, tergantung pada ketajaman analisis permasalahan. Selain teori, hasil-hasil penelitian lain yang relevan, dapat juga disajikan dengan menyebutkan sumber referensinya (Tim Penyusun Fakultas Sains dan Teknologi, 2015:16).

Kerangka teori suatu penelitian merupakan kumpulan konsep yang saling kait yang berfungsi untuk memandu penelitian, menentukan hal-hal yang akan diukur atau diuji dalam penelitian, dan menunjukkan hubungan empiris yang akan 
diicari melalui penelitian. Kerangka teori terdiri atas konsep dan teori yang ada yang digunakan untuk penelitian. Kerangka teori harus memberikan pemahaman tentang teori dan konsep yang relevan dengan topik penelitian dan yang terkait dengan bidang pengetahuan yang lebih luas yang dipertimbangkan.

Telaah pustaka merupakan uraian tentang teori, konsep, atau pendekatan yang relevan dengan topik penelitian. Uraian telaah pustaka diperoleh dari berbagai sumber kepustakaan/referensi yang bisa dipertanggungjawabkan secara ilmiah. Sumber telaah pustaka yang utama adalah jurnal ilmiah (internasional/nasional) dan buku teks. Sumbersumber lainnya antara lain adalah dokumen, artikel ilmiah, laporan hasil penelitian sebelumnya, monograf dan sumber lain yang dapat dipertanggungjawabkan secara ilmiah (Tim Penyusun Fakultas Ekonomi dan Bisnis, 2018:11). Literatur dan sumber kepustakaan hendaklah relevan dan mutakhir (maksimal 10 tahun terakhir) yang bersumber dari buku-buku, artikel dalam jurnal bertaraf nasional atau internasional.

Kemampuan mahasiswa dalam menulis proposal penelitian skripsi dilihat dari aspek sistematika penulisan sebagian besar berkualifikasi baik. Hal ini menunjukkan mahasiswa telah mampu menulis sistematika penulisan proposal penelitian skripsi. Mahasiswa telah mampu menulis sistematika dalam berbagai jenis penelitian seperti penelitian kuantitatif, kualitatif, tindakan kelas, kebahasaan, dan sastra. Hal ini sesuai dengan sistematika penulisan proposal penelitian proposal yang baik menurut Tim Penyusun Fakultas Sains dan Teknologi. (2015:5) bahwa sistematika proposal skripsi yang baik disusun sesuai dengan sistematika jenis penelitiannya. Secara umum, proposal skripsi terdiri atas halaman sampul, halaman persetujuan, pendahuluan (latar belakang, rumusan masalah, tujuan penelitian, manfaat penelitian, definisi istilah/operasional), kerangka (landasan) teori dan kajian pustaka yang berisi kajian teoretis terkait dengan rumusan masalah, hasil penelitian yang relevan, kerangka berpikir, dan hipotesis (jika diperlukan), metode penelitian (jenis dan rancangan penelitian, lokasi penelitian, populasi dan sampel penelitian, instrumen penelitian dan teknik pengumpulan data, dan teknik analisis data, dan daftar pustaka. 


\section{b. Kesulitan Menulis Proposal Penelitian Skripsi Mahasiswa Semester VII Pendidikan Bahasa Indonesia}

Hasil penelitian dari jawaban melalui WhatsApp (WA) bahwa sebagian besar mahasiswa mengalami kesulitan menulis proposal. Penelitian ini mendukung penelitian yang dilakukan Aisiah \& Firza (2019) mahasiswa pada umumnya mengalami kendala dalam penulisan proposal penelitian skripsi.

Pada Bab I Pendahuluan, mahasiswa mengalami kesulitan pada menulis permasalahan dan rumusan masalah, dan mengembangkannya serta mengidentifikasi masalah. Dalam latar belakang masalah hendaknya dimuat alasan-alasan penting dan perlunya meneliti masalah dan juga dijelaskan kedudukan masalah yang diteliti dalam lingkup permasalahan yang lebih luas (Sugiyono, 2015; Tim Penyusun Fakultas Sains dan Teknologi, 2015:16). Rumusan masalah memuat pernyataan singkat tentang masalah yang diteliti, batasan masalah yang diteliti, yang dapat disusun dalam kalimat pertanyaan. Penelitian ini mendukung hasil penelitian Zuriati (2020), Iswahyudi (2014), dan Rismen (2015) yang menyatakan bahwa mahasiswa mengalami kesulitan dalam menulis pendahuluan proposal penelitian skripsi.

Mahasiswa mengalami kesulitan di dalam menulis BAB II Landasan Teori dan Kajian Pustaka yang mengutip dari buku, jurnal, dan yang lain. Selain mengalami kesulitan dalam menulis Landasan Teori dan Kajian Pustaka, mahasiswa mengalami kesulitan dalam kerangka berpikir dan pengajuan hipotesis. Penelitian ini mendukung hasil penelitian Zuriati (2020) yang menyatakan mahasiswa mengalami kesulitan dalam menulis landasan teori dan kajian pustaka.

Mahasiswa mengalami kesulitan pada BAB III Metodologi Penelitian. Hal in mendukung penelitian Zuriati (2020) yang menyimpulkan bahwa mahasiswa pada umumnya mengalami kesulitan dalam penulisan metodologi penelitian. Pada Bab Metodologi ini mengalami kesulitan dalam menentukan metode penelitian, peenentuan pengambilan sampel dan jenis sampel, instrumen dan teknik pengumpulan data, serta penggunaan rumus statistik dalam analisis data. 


\section{Simpulan dan Saran}

Berdasarkan hasil penelitian dan pembahasan dapat disimpulkan bahwa kemampuan mahasiswa semester VII Program Studi Pendidikan Bahasa Indonesia FKIP Universitas Bengkulu tergolong cukup. Hal ini berarti bahwa mahasiswa belum mampu menulis proposal penelitian skripsi dengan baik. Mahasiswa mengalami kesulitan dalam menulis proposal penelitian skripsi pada bagian (1) pendahuluan, yaitu penulisan judul, masalah dan rumusan masalah, (2) penulisan landasan teori dan kajian pustaka, (3) metodologi penelitian, yaitu pada penentuan metode penelitian, penyusunan instrumen dan teknik pengambilan data serta analisis data penelitian.

Berdasarkan simpulan di atas disarankan kepada Program Studi Pendidikan Bahasa Indonesia FKIP Universitas Bengkulu untuk membantu mahasiswa agar betul-betul memahami cara menyusun proposal penelitian skripsi dengan cara melakukan pelatihan penulisan proposal skripsi sebelum mengajukan judul dan menulis proposal penelitian skripsi. Di samping itu, para dosen, khususnya dosen metode penelitian pendidikan bahasa dan sastra, penelitian bahasa dan sastra serta seminar pendidikan, bahasa, dan sastra untuk membantu mahasiswa agar dapat menyusun proposal dengan baik dengan cara memberi tugas membuat berbagai macam proposal penelitian skripsi.

\section{Daftar Pustaka}

Aisiah, A., \& Firza, F. (2019). Kendala yang Dihadapi Mahasiswa Jurusan Sejarah dalam Menulis Proposal Skripsi. Diakronika, 18(2), 90. doi:10.24036/diakronika/vol18-iss2/70

Ardimen, A. (2017). Peningkatan Kompetensi Profesional Calon Konselor dalam Menulis Proposal Penelitian. Islamic Counseling: Jurnal Bimbingan Konseling Islam, 1(1), 64-93. doi:10.29240/jbk.v1i1.225

Doni, S., \& Edi, S. (2019). Kemampuan Mahasiswa Fakultas Ekonomi Universitas Tridinanti Palembang dalam Menulis Proposal Penelitian. Parataksis: Jurnal Bahasa, Sastra, dan Pembelajaran Bahasa Indonesia, 2(1). doi:10.31851/parataksis.v2i1.4138 
Gani, Erizal. (2019). Komponen-Komponen Karya Ilmiah. Bandung: Putaka Reka Cipta.

Iswahyudi. (2014). Permasalahan Penyusunan Tugas Akhir Mahasiswa Bidang Pengkajian Seni. Program Studi Pendidikan Seni Kerajinan. Skripsi. FBS UNY.

Kristanto, P. H., Pm., S., \& Setyorini, S. (2014). Hubungan antara Kepercayaan Diri dengan Kecemasan dalam Menyusun Proposal Skripsi. Satya Widya, 30(1), 43. doi:10.24246/j.sw.2014.v30.i1.p43-48

Rismen, S. (2015). Analisis Kesulitan Mahasiswa dalam Penyelesaian Skripsi di Prodi Pendidikan Matematika STKIP PGRI Sumbar. Lemma, 1(2).

Sanjaya, Wina. (2014). Penelitian Pendidikan: Jenis, Metode, dan Prosedur. Jakarta: Kencana Prenada Media Group.

Sugiyono. (2015). Cara Mudah Menyusun Skripsi, Tesis, dan Disertasi. Bandung: Alfabeta.

Susetyo \& Noermanzah. (2020). Model of Literature Review in Research Thesis of Students Education Master Program at FKIP Bengkulu University. International Journal of Scientific and Technology Research, 9(2). http://www.ijstr.org/paper-references.php?ref=IJSTR-0120-29993

Susetyo. (2019). Metodologi Penelitian Pendidikan untuk Mahasiswa Pendidikan Bahasa Indonesia. Bengkulu: UPP FKIP Universitas Bengkulu.

Tim Penyusun Fakultas Ekonomi dan Bisnis. (2018). Pedoman Penulisan Skripsi. Purwokerto: Unsoed.

Tim Penyusun Fakultas Ilmu Pendidikan. (2017). Pedoman Penulisan Proposal. Universitas Negeri Semarang.

Tim Penyusun Fakultas Sains dan Teknologi. (2015). Pedoman Penulisan Skripsi. Surabaya: Universitas Airlangga.

Zuriati, D. (2020). Kesulitan Menulis Proposal Penelitian oleh Mahasiswa STIBA Persada Bunda Pekanbaru. Menara IImu, 11(74). https://jurnal.umsb.ac.id/index.php/menarailmu/article/view/71 